\title{
The Effect of Computer Aided Education on the Skill of Word Stressing in Teaching Turkish as a Foreign Language
}

\author{
Gurbet Sariman ${ }^{1}$, Didem Çetin ${ }^{2, *}$ \\ ${ }^{1}$ School of Foreign Languages, Muğla Sitkı Koçman University, Turkey \\ ${ }^{2}$ Department of Turkish Education, Muğla Sitkı Koçman University, Turkey
}

Copyright $\bigcirc 2018$ by authors, all rights reserved. Authors agree that this article remains permanently open access under the terms of the Creative Commons Attribution License 4.0 International License

\begin{abstract}
The purpose of the study is to investigate the effect of computer aided education on the skill of word stressing in teaching Turkish as a foreign language. Single group pre-test and post-test experimental design was used in the study. The group of the study consisted of 23 foreign students in Muğgla Sitkı Koçman University School of Foreign Languages Turkish Preparatory Program in 2014-2015 academic year. To improve the skill of word stressing, computer-assisted prosody training was applied to the students for 5 weeks. Data of the study was obtained from the "Word Stressing Measurement Tool" and the audio recordings of the students. In addition to these, words and compound words in the "Word Stressing Measurement Tool" were grouped according to the rules of Turkish word stress. The audio recordings taken from the students to determine the level of students' success in word stressing was examined and assessed in terms of fundamental frequency on Praat 3.8.47 speech analysis program. These results were analyzed using paired samples t-test on SPSS 20.0 statistical package software. Whether there is a significant difference between the pre-test and post-test scores of the students in the groups of the words and compound words in the "Word Stressing Measurement Tool" formed in terms of the rules of Turkish word stress and in the groups of the participants formed according to their mother tongue or the official language spoken in their countries were found out. As a result of the research, it was found that there was a significant increase in the participants' success of word stressing. These results indicated that computer aided word stress training has an effect on improving the skill of word stressing in teaching Turkish as a foreign language.
\end{abstract}

Keywords Teaching Turkish as a Foreign Language, Computer Assisted Prosody Training, Suprasegmental Features, Word Stress

\section{Introduction}

Factors such as language politics encompassing the European Union member countries and candidate countries, developing technology, multilingualism, multiculturalism, increased international communication and mobility influence the change of language education policies and practices in our country. As pointed out by Sığırc1 [1], with the European Language Passport, steps have been taken to change the language teaching methods applied for many years in Turkey; an approach that emphasizes the teaching of language skills has become more important than teaching grammar according to the Common European Framework of Reference for Languages (Council of Europe, 1998). Within the context of these changes, Turkish is taught to foreign citizens residing in our country for different reasons, books are written in this field and contributions are made to the field through academic studies.

When the historical process is examined, it is seen that Turkish has been taught and learned as a foreign language in the Asian, European and African continents. The works written in this field are dominated by works produced in Arabic and Persian languages. However, in recent years, the works done for the speakers of other languages have been gathering momentum. In line with the decisions made, attempts have been made to regulate the education system and educational settings in our country, which is among the candidate countries of the European Union. Turkish courses are being offered at different levels in universities to foreign students who come to Turkey within the framework of various programs and projects and whose numbers are increasing each day. Decisions made, approaches and practices adopted in our country in relation to foreign language teaching and the requirements of this age have made it a necessity to teach Turkish to foreigners and to conduct studies on teaching Turkish as a foreign language. 
The main objective of teaching Turkish as a foreign language is to impart basic language skills to foreign students and to enable them to complete their studies in their majors in Turkish universities by using this language and more importantly to make them individuals who can establish healthy communication in the Turkish society.

Learning a foreign language involves acquiring a considerable knowledge of the many different aspects of language, including vocabulary, grammar, and pronunciation. The relative importance given to each aspect varies amongst teaching practices, but in all cases an understanding of native speech patterns and the ability to amount to native-like pronunciation are important components of foreign language learning, influencing both the student's comprehension and intelligibility [2]. To reach this goal, speaking activities should be done at every stage of the foreign language teaching process.

Rivers [3] points out that all persons had experience of having great difficulty in understanding what they are trying to say when listening to a foreigners' speaking language, not because of their lack of knowledge of vocabulary and language structure, but because the sounds they produce seemed peculiar and the voice rose and fell in unexpected places. This sentence emphasizes a well-known fact that most of the people learning a foreign language encounter some problems of pronunciation of the new language, owing to some contributory factors. One of these factors is the native language factor.

According to Demircan [4], when the difficulties stemming from mother tongue while teaching a foreign language are considered, five different groupings can be produced:

1. Non-existence of some phonemes in the learner's mother tongue or in the target language,

2. Different pronunciation of phonemes in the mother tongue and in the target language,

3. The stress on phonemes, words or phrases is different in the mother tongue from the target language, [5]

4. The syntax in the mother tongue is different from the target language,

5. Non-existence of affixes added to phonemes or words in the mother tongue or in the target language.

As pointed out by Rivers, Demircan and Avery and Ehrlich, foreign students experience difficulties in the pronunciation of the target language for different reasons. Particularly in the field of teaching Turkish as a foreign language, there is a paucity of research on the development of pronunciation skills and almost no pronunciation activities are included in the textbooks used in Turkish teaching centers. This shows that there is a need for applied studies in the field [3, 4, 5].

Today, due to technological developments, the proliferation of information sharing on the internet has increased the importance of communication and therefore that of language. This necessitates language education complying with the requirements of our age. While there are a limited number of studies focusing on pronunciation in the field of teaching Turkish as a foreign language [6, 7, $8,9]$ there is almost no applied study on teaching suprasegmental units in speech and particularly on teaching word stress.

In the study conducted by Özkan [8] on the first-year students of English Language Teaching Department to teach word stress, students were given computer assisted training for 5 weeks and as a result of this training, the students' success in using stress in word pronunciation was found to be improved. Çetin [10] conducted a study to investigate the effect of the computer assisted prosody training given to the third year students of Turkish Education Department for 10 weeks on the perception and reflection skills of stress, tone and emotion. As a result of this study, it was found that there was a significant increase in stress, tone and emotion perception and reflection achievement levels of the participants. In the study by Bagshaw [11], an automatic prosodic analysis system allowing the students to compare the prosodic elements in their speeches with the prosodic elements in the speeches of native speakers of English was developed. At the end of the study, it was noted that this developed system could be used as an instructional tool in the teaching of pronunciation (stress and tone). Hardison [12] investigated the effect of computer-assisted prosody training given to the native speakers of English learning French on their pronunciation and prosodic skills and found a considerable improvement in the pronunciation and prosodic skills of the students having received this training. Fujimori, Yoshimura and Yamane [13] gave prosody training to 40 Japanese students learning English at A2 level by using the computer-assisted instructional material they had developed and concluded that the computer-assisted and visual prosody training was as effective as verbal instruction.

\subsection{Stress}

For the message to be conveyed to the listener and to be turned into a meaningful conversation, it is necessary to select the words suitable for the purpose and the context, to pronounce the selected words in a correct phonemic order and with a correct articulation, to create a meaningful word order by bringing words together in a correct sequence and to pronounce the constructed sentences with the prosody suitable for the meaning and emotion [14].

Stress, one of the prosodic elements that make speech fluent and effective, is defined in the most general terms as "the expression of a certain syllable in a word in a more stressed manner than the others". According to Coşkun [15], stress is the "phonetically, the most strongly toned (vibrated) sound in a word"; according to Demircan [16], 
it is "the emphasis of breath that falls on a syllable while speaking". Akbayır [17] points out that stress adds affective value to an utterance, keeps the attention of the listener alive facilitating the grasp of the meaning. Bilgin [18] argues that speeches or readings without stress result in monotony; misplacement of stress makes comprehension more difficult and leads to misunderstandings.

When different studies are reviewed, it is seen that stress is classified under the following headings in Turkish [16, 19-30]:

- $\quad$ Expiratory stress

- Logical stress

- Harmonic stress

- Reinforcement stress

- Natural stress

- Arbitrary stress

- Affixal stress

- Word stress

- Group stress

- Sentence stress

In addition, there is a meaning distinguishing stress in Turkish used to distinguish homonymic words [20]. In Figure-1, some homonymic words and the basic frequency analysis charts of these words are seen:
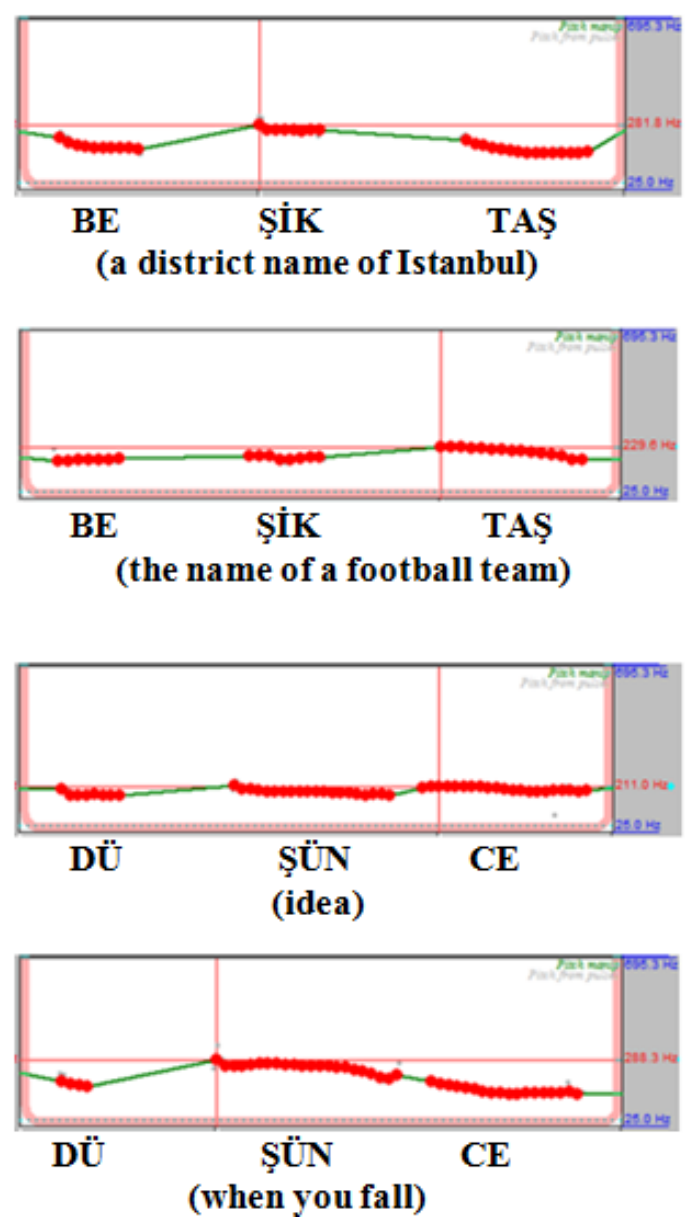

Figure 1. Change Styles $\rightarrow$ Styles Menu
As can be seen in Figure-1, while the stress is on the "-şik" syllable in the word Beşiktaş, which is a name of a district, it is on the "-taş" syllable in the world Beşiktaş, which is a name of a football club. While the stress is on the last syllable "-ce" in the word "düşünce" meaning "idea", in the word "düşünce", which is an adverb meaning "when he falls", it is on the "-şün" syllable. As in these homonymic words, in words having the same phonemic order, stress is the meaning distinguishing element.

Stress is of great importance for people learning Turkish as a foreign language to recognize the difference between the meanings of homonymic words and accurately pronounce them and understand which meaning a homonymic word uttered by someone else refers to. According to Çetin [14], the fact that foreign students have difficulty in distinguishing the meanings of homonymic words leads them to stress these words incorrectly during their speech. Moreover, putting stress on the wrong syllable in non-homonymic words also causes the listener to be unable to understand this word and also the listener's making the speaker repeat the word, thus negatively affecting the flow of speech.

When learners of Turkish as a foreign language put the stress according to the rules of their own language, the flow of speech is distorted and they can be laughed at. This makes these learners hesitant about using the language as they are afraid of making mistakes; thus, they cannot express themselves freely and comfortably. According to Işık and Erol [31], a speaker who cannot create a harmony in his/her utterances with stress cannot keep the listener's interest alive no matter how interesting, exciting and useful topics he/she is talking about. What make the speech of beginner Turkish learners ridiculous is their stress-related mistakes distancing their speech from the natural form. Thus, stress is an element that should be focused on while teaching speaking in Turkish both as a mother tongue and as a foreign language.

\subsection{Computer Aided Prosody Training}

Suprasegmental units called as prosodic elements (stress, tone, rhythm, time, juncture, and pause) are elements that add an affective value and meaning to the sound, show the harmony between what is meant and what is uttered; thus, have a meaning distinguishing function [32]. As the instructional approaches to teaching of suprasegmental units based on rising of students' awareness only by means of listening are not effective, the prosody training given in a computer environment assisted with voice analysis programs has been proved to be much more permanent and effective. In the applied studies, it has also been concluded that the computer-assisted instruction is effective in developing students' prosodic skills [8-13, 33, 34].

There are audio analysis programs such as Real-Time 
Pitch (RTP), Visi-Pitch, MDVP, and Praat, which are used in the treatment of speech impairments and can also make suprasegmental units such as stress and tone visible. While Real-Time Pitch, Visi-Pitch and MDVP are mostly used for treatment purposes, Praat audio analysis program can be used for both treatment and educational purposes. Praat, which can present audio and visual data simultaneously, improves the efficiency of learning in prosody training; moreover, it is also used in many parts of the world, especially in foreign language education [10].

The purpose of the current study is to develop the word stressing skills of students who are learning Turkish as a foreign language and whose mother or official languages are Arabic, Persian, Russian or French by giving them computer assisted prosody training. The current study sought answers to the following research question and sub-questions in order to elicit the effect of computer assisted instruction in Turkish teaching on the students' word stressing skill.

\subsection{Problem Statement of the Study}

What is the effect of computer assisted instruction in Turkish teaching on the students' word stressing skill?

Sub-problems of the study:

1. Is there a significant difference between the pre-test and post-test scores of the word stressing skill of the students undergoing computer-assisted training?

2. Is there a significant difference between the pre-test and post-test scores of the word stressing skill of the students undergoing computer-assisted training in terms of the rules of word stress in Turkish?

3. Is there a significant difference between the pre-test and post-test scores of the word stressing skill of the students undergoing computer-assisted training in terms of their mother tongue or the official language of their countries?

\section{Methods}

The current study employed the quasi-experimental single group pre-test and post-test model. In this model, a pre-test is administered to a single group to measure their knowledge about the subject of interest and at the end of the application; the same test is administered to the same group to measure the same knowledge. If the data obtained reveal a significant difference between the pre-test results and post-test results, then this difference is accepted to have been stemmed from the application [35].

At the application stage of the study, the students were given theoretical information about the word stress in Turkish and then the Computer Assisted Turkish Word Stress Training developed by the researcher by seeking expert opinions was administered to the students for five weeks, a total of 10 class hours. During the training, as the students were asked to participate in the pronunciation activity one by one, the 23 participating students were divided into two groups of 11 students and 12 students each to provide equal and adequate time for each student. In each group, the same activities were conducted. The first activity conducted to improve the students' word stressing skill was the TA-TA-TA-TA-TA activity. In this activity, the students were asked to pronounce the syllable "TA" consecutively five times as "TA-TA-TA-TA-TA" and each time they were asked to put the stress on a different "TA" syllable (TA-ta-ta-ta-ta / ta-TA-ta-ta-ta / ta-ta-TA-ta-ta / ta-ta- ta-TA-ta / ta-ta -ta-ta-TA). In another activity, the stress features of Turkish were explained by using sample words and phrases. During the explanations, the image of the sound analysis of each word done with Praat 3.8.47 program was displayed on the screen; then each student was asked to pronounce these words. The images of the analyses of the students' sound recordings was displayed on the screen by means of a projector; thus, the students were able to both listen to the words and see the stress analyses, which allowed them to see whether they put the stress on the correct syllable.

\subsection{Sampling}

The sampling of the current research is comprised of 23 foreign students randomly selected from among the 31 students enrolled at the Muğla Sitkı Koçman University Foreign Languages School Turkish Preparatory Program in 2014-2015 academic year. The countries and mother tongues/official languages of the participating students are given in Table 1:

Table 1. Students' Countries and Mother Tongues/Official Languages

\begin{tabular}{|c|c|c|}
\hline Countries & $\begin{array}{c}\text { Mother Tongues or Official } \\
\text { Languages }\end{array}$ & $\mathbf{n}$ \\
\hline $\begin{array}{c}\text { Syria, Yemen and Saudi } \\
\text { Arabia }\end{array}$ & Arabic & 8 \\
\hline Afghanistan & Persian & 4 \\
\hline Kazakhstan and Ukraine & Russian & 6 \\
\hline Morocco, Niger and Chad & French & 5 \\
\hline \multicolumn{2}{|c|}{ Total } & 23 \\
\hline
\end{tabular}

\subsection{Data Collection}

The data related to the students' word stressing skills were obtained by using "The Word Stress Measurement Tool" developed by the researcher on the basis of expert opinions. In this tool there are a total of 85 words and phrases. The students were asked to pronounce these words and phrases and then their pronunciations were analyzed by using Cool Edit Pro 2.1 program.

The words and phrases in "The Word Stress Measurement Tool" were divided into six main groups in terms of the word stress rules of Turkish. In the first group, 
there are the words which are stressed on the last syllable and the stress shifts to the last syllable when a suffix is added; in the second group, there are place names; in the third group, there are question words, conjunctions, reinforcement adjectives and some compound words which are stressed on the first syllable; in the fourth group, there are the words including suffixes carrying the stress to the syllable prior to the suffix; in the fifth group, there are homonymic words and in the sixth group, there are phrases in which stress is put on the last syllable of the first word.

The general distribution of the words and phrases in the Word Stress Measurement Tool is given below in Table 2.

Table 2. Words and Phrases in the Word Stress Measurement Tool

\begin{tabular}{|c|c|c|}
\hline \multicolumn{2}{|r|}{ Words and Phrases } & $\mathbf{n}$ \\
\hline \multicolumn{2}{|c|}{$\begin{array}{l}\text { 1. Words which are stressed on the last syllable and the } \\
\text { stress shifts to the last syllable when a suffix is added }\end{array}$} & 8 \\
\hline \multicolumn{2}{|l|}{ 2. Place Names } & 10 \\
\hline \multirow{5}{*}{$\begin{array}{l}\text { 3. Words having } \\
\text { the stress on the } \\
\text { first syllable }\end{array}$} & Some compound words & 2 \\
\hline & Question words & 2 \\
\hline & Conjunctions & 2 \\
\hline & Exclamations & 2 \\
\hline & Reinforcement adjectives & 2 \\
\hline \multirow{12}{*}{$\begin{array}{l}\text { 4. Words having } \\
\text { suffixes carrying } \\
\text { stress to the } \\
\text { syllable prior to } \\
\text { the suffix }\end{array}$} & "-leyin" & 2 \\
\hline & “-gil" & 2 \\
\hline & "-ca / -ce" & 4 \\
\hline & Negation suffixes “-ma / -me” & 1 \\
\hline & Question suffixes “-mı / -mi” & 2 \\
\hline & $\begin{array}{l}\text { Complementary verb suffixes } \\
\text { “-di, -miş, -dir, -se" and present simple } \\
\text { tense suffixes }\end{array}$ & 9 \\
\hline & $\begin{array}{l}\text { Personal pronoun suffixes (except for } \\
3^{\text {rd }} \text { person imperative suffixes) }\end{array}$ & 3 \\
\hline & $\begin{array}{l}\text { "-le, -le" suffixes as the contracted } \\
\text { forms of "ile" }\end{array}$ & 2 \\
\hline & $\begin{array}{l}\text { "-ken" suffix as the contracted form of } \\
\text { "iken" }\end{array}$ & 2 \\
\hline & Gerundium suffix “-madan” & 2 \\
\hline & Present continuous suffix "-yor" & 2 \\
\hline & Diminutive suffix & 2 \\
\hline \multicolumn{2}{|c|}{ 5. Homonymic words } & 11 \\
\hline \multirow{5}{*}{ 6. Phrases } & Noun phrase and adjective phrase & 5 \\
\hline & Compound words & 2 \\
\hline & $\begin{array}{l}\text { Phrases constructed by adding } \\
\text { "Hanım", "Bey", etc. to personal names }\end{array}$ & 2 \\
\hline & $\begin{array}{l}\text { Compound words formed with } \\
\text { auxiliary verbs }\end{array}$ & 2 \\
\hline & Cardinal number adjectives & 2 \\
\hline \multicolumn{2}{|r|}{ Total } & 85 \\
\hline
\end{tabular}

Prior to and following the application in the current study, the students were subjected to pre-test and post-test by pronouncing the words and phrases in the Word Stress Measurement Tool.

\subsection{Data Analysis}

The data collected as a result of the students' pronouncing a total of 85 words and phrases in the Word Stress Measurement Tool were analyzed in terms of the basic frequency in Praat 3.8.47 sound analysis program. In this way, it was determined whether the students had correctly stressed the words and phrases; 1 point was assigned to each correctly stressed word or phrase. In order to determine whether the difference between the students' pre-test and post-test scores is significant, independent samples t-test was run in SPSS 20.0 program package. Thus, it was determined whether there is a significant difference between the students' pre-test and post-test scores in terms of the word stress rules of Turkish and the students' mother tongues or official languages. 3. Findings

In line with the main objective of the current study, the answer to the question "What is the effect of computer assisted instruction in Turkish teaching on the students' word stressing skill?" was sought and the findings are presented below.

Within the context of the first sub-problem of the study, it was investigated whether there is a significant difference between the pre-test and post-test scores of the students learning Turkish as a foreign language and subjected to the computer assisted instruction. The t-test results related to the students' pre-test and post-test scores taken from the Word Stress Measurement Tool are presented in Table 3.

Table 3. General Findings related to the Students' Pre-test and Post-test Scores taken from the Word Stress Measurement Tool

\begin{tabular}{|c|c|c|c|c|c|c|}
\hline & $\mathrm{n}$ & $\bar{X}$ & $\mathrm{~S}$ & $\mathrm{Sd}$ & $\mathrm{t}$ & $\mathbf{P}$ \\
\hline Pre test & 23 & $\mathbf{4 0 . 1 7}$ & 15.04 & 22 & 10.05 & $\mathbf{. 0 0 0}$ \\
\hline Post test & 23 & $\mathbf{7 1 . 0 8}$ & 5.55 & & & \\
\hline
\end{tabular}

When the students' pre-test and post-test scores taken from the Word Stress Measurement Tool were examined, it was seen that the students' word stressing skills significantly improved after they had taken computer assisted word stress training $[\mathrm{t}(23)=10,05, \mathrm{p}<0.01]$. While the students' pre-test mean score from the Word Stress Measurement Tool was 40.17, their post-test mean score increased to 71.08 as a result of the computer assisted prosody training. This shows that their word stressing achievement increased by $37.21 \%$. Thus, it can be argued that the computer assisted word stress training has a significant effect on the development of the students' word stressing skills.

Within the context of the second sub-problem of the study, it was investigated whether there is a significant 
difference between the pre-test and post-test scores of the students learning Turkish as a foreign language and subjected to the computer assisted instruction in terms of the word stress rules of Turkish. In Table 4, t-test results related to the pre-test and post-test scores taken from the Word Stress Measurement Tool in terms of the word stress rules of Turkish are presented.

In Table 4, it is seen that considering the rules of word stress in Turkish, the greatest improvement of word stressing skill occurred in the place names $(42.6 \%)$. They are followed by the homonymic words $(40.27 \%)$, the words having suffixes carrying stress to the syllable prior to the suffix (37.03\%), the phrases having the stress on the last syllable of the first word $(33.46 \%)$, the question words, conjunctions, reinforcement adjectives and compound words having the stress on the first syllable $(31.8 \%)$ and the words which are stressed on the last syllable and the stress shifts to the last syllable when a Suffix is added (31\%). As it can be seen, the students' word stressing skills significantly improved for each group after the computer assisted word stress training when the success of the rule groups of word stress in Turkish are analyzed.

Within the context of the third sub-problem of the study, it was investigated whether there is a significant difference between the pre-test and post-test scores of the students learning Turkish as a foreign language and subjected to the computer assisted instruction in terms of their mother tongues and official languages. The students were divided into groups as the speakers of Arabic, the speakers of Persian, the speakers of French and the speakers of Russian. Through this classification, it was intended to observe the effect of the students' mother tongues on their Turkish word stressing skills. In Table 5, t-test results related to the students' pre-test and post-test scores taken from the Word Stress Measurement Tool in terms of their mother tongues are presented.

Table 4. Findings related to the Pre-test and Post-test Scores taken from the Word Stress Measurement Tool in terms of the Word Stress Rules of Turkish

\begin{tabular}{|c|c|c|c|c|c|c|c|c|}
\hline & & $\mathrm{n}$ & $\bar{X}$ & $\mathrm{~S}$ & $\mathrm{Sd}$ & $\mathrm{t}$ & $P$ & $\begin{array}{l}\text { Rate of Achievement } \\
\text { Increase }\end{array}$ \\
\hline \multirow{2}{*}{$\begin{array}{l}\text { 1. Words which are stressed on } \\
\text { the last syllable and the stress } \\
\text { shifts to the last syllable when a } \\
\text { suffix is added }\end{array}$} & Pre-test & 23 & 4,65 & 2,51 & 22 & 4,35 & ,000 & \multirow{2}{*}{$31 \%$} \\
\hline & Post-test & 23 & 7,13 & 1,25 & & & & \\
\hline \multirow{2}{*}{ 2. Place names } & Pre-test & 23 & 3,91 & 2,55 & 22 & 7,92 & ,000 & \multirow{2}{*}{$42,6 \%$} \\
\hline & Post-test & 23 & 8,17 & 1,33 & & & & \\
\hline \multirow{2}{*}{$\begin{array}{l}\text { 3. Words having the stress on } \\
\text { the first syllable }\end{array}$} & Pre-test & 23 & 4,86 & 2,73 & 22 & 4,82 & 000 & \multirow{2}{*}{$31,8 \%$} \\
\hline & Post-test & 23 & 8,04 & 1,69 & & & & \\
\hline \multirow{2}{*}{$\begin{array}{l}\text { 4. Words having suffixes } \\
\text { carrying stress to the syllable } \\
\text { prior to the suffix }\end{array}$} & Pre-test & 23 & 15,91 & 8,07 & 22 & 7,90 & , 000 & \multirow{2}{*}{$37,03 \%$} \\
\hline & Post-test & 23 & 28,13 & 2,80 & & & & \\
\hline \multirow{2}{*}{ 5. Homonymic words } & Pre-test & 23 & 3,78 & 1,53 & 22 & 8,62 &, 000 & \multirow{2}{*}{$40,27 \%$} \\
\hline & Post-test & 23 & 8,21 & 2,25 & & & & \\
\hline \multirow{2}{*}{ 6. Phrases } & Pre-test & 23 & 7,04 & 3,63 & 22 & 6,46 & , 000 & \multirow{2}{*}{$33,46 \%$} \\
\hline & Post-test & 23 & 11,39 & 2,03 & & & & \\
\hline
\end{tabular}

Table 5. Findings related to the Students' Pre-test and Post-test Scores taken from the Word Stress Measurement Tool in terms of their Mother Tongues and Official Languages

\begin{tabular}{|c|c|c|c|c|c|c|c|c|}
\hline & & $\mathrm{n}$ & $\bar{X}$ & $\mathrm{~S}$ & $\mathrm{Sd}$ & $\mathrm{t}$ & $\mathrm{P}$ & $\begin{array}{c}\text { Rate of Achievement } \\
\text { Increase }\end{array}$ \\
\hline \multirow{2}{*}{$\begin{array}{l}\text { Students whose mother } \\
\text { tongue is Arabic }\end{array}$} & Pre-test & 8 & 46,87 & 16,05 & 7 & 4,44 & ,003 & \multirow{2}{*}{$24,27 \%$} \\
\hline & Post-test & 8 & 67,50 & 5,90 & & & & \\
\hline \multirow{2}{*}{$\begin{array}{l}\text { Students whose mother } \\
\text { tongue is French }\end{array}$} & Pre-test & 5 & 35,60 & 11,43 & 4 & 6,64 & ,003 & \multirow{2}{*}{$43,29 \%$} \\
\hline & Post-test & 5 & 72,40 & 3,57 & & & & \\
\hline \multirow{2}{*}{$\begin{array}{l}\text { Students whose mother } \\
\text { tongue is Persian }\end{array}$} & Pre-test & 4 & 31,25 & 18,98 & 3 & 5,84 &, 010 & \multirow{2}{*}{$50,58 \%$} \\
\hline & Post-test & 4 & 74,25 & 4,34 & & & & \\
\hline \multirow{2}{*}{$\begin{array}{l}\text { Students whose mother } \\
\text { tongue is Russian }\end{array}$} & Pre-test & 6 & 41,00 & 12,53 & 5 & 6,52 & ,001 & \multirow{2}{*}{$37,24 \%$} \\
\hline & Post-test & 6 & 72,66 & 5,64 & & & & \\
\hline
\end{tabular}


As can be seen in Table 5, considering the students' mother tongues or official languages, the greatest increase in the word stress achievement occurred in the students whose mother tongue or official language is Persian $(50.58 \%)$. They are followed by the French speakers (43.29\%), the Russian speakers (37.24\%) and the Arabic speakers $(24.27 \%)$. It can be seen that the students' word stressing skills significantly improved for each group after the computer assisted word stress training when the success of nationality or official language groups of students are analyzed.

\section{Results and Discussion}

In the current study investigating the effect of computer assisted word stress training in Turkish teaching on the students' word stressing skills, five-week computer assisted word stress training was applied to the students enrolled at Muğla Sitkı Koçman University Foreign Languages School Turkish Preparatory Program and as a result of this training, the students' word stressing achievement was found to have improved by $37.21 \%$. This shows that the computer assisted word stress training was effective in improving the students' word stressing skills. This finding is supported by other studies on computer assisted prosody training $[8,10,11,12,13,32$, 36].

In the evaluation conducted in terms of the grouping of the rules of Turkish word stress, it was found that the highest achievement increase was obtained in the place names with $42.6 \%$ and in the homonymic words including meaning distinguishing stress with $40.27 \%$. The achievement increase in the words having suffixes carrying the stress onto the syllable prior to the suffix was found to be $37.03 \%$. This achievement rate, when compared to the other rates, indicates an average achievement increase. The rate of achievement increase in the stressing of the phrases is $33.46 \%$. When compared to the other rates, this seems to be relatively lower. As there are noun phrases and compound words within the phrases, the students need to analyze the syntax while perceiving the stress. Therefore, they may have considered the stress separately for each word in the phrase; thus, the relatively lower rate of achievement increase in these phrases when compared to other word groups seems to be normal.

The mean achievement increase in putting the stress on the correct syllable in the third group of words including some compound nouns, question words, conjunctions, exclamations and reinforcement adjectives having the stress on the first syllable was found to be $31.8 \%$. This rate of increase seems to be relatively lower when compared to the other rates. The students may have focused on different meanings and types of these words, while pronouncing them.

The lowest rate of achievement increase was observed in the words having the stress on the last syllable and the stress shifts to the last syllable when a new suffix is added. This might be because the Turkish is an agglutinating language, but the students' mother tongues are inflexible languages and from different language families.

The analysis conducted in relation to the students' mother tongues or official languages revealed that the highest rate of achievement increase was accomplished by the students speaking Persian with $50.58 \%$ and then the students speaking French with 43.29\%; the lowest rate of achievement increase was accomplished by the students speaking Arabic with $24.27 \%$. These results give rise to two questions: Why was the highest rate of achievement increase obtained by the French speakers; Why was the lowest rate of achievement increase obtained by the Arabic speakers? Though French and Persian seem to be distant from each other in terms of the geographical regions they are used in, they both are from the Indo-European language family; thus, they may have some common aspects. The answer to the second question can be explained as follows: While the contact of Arabic with the Turkish language started after the birth of Islam, the contact of Persian started long before the birth of Islam. Both in the lands of Iran and of Central Asia, Turks lived in close contact with Iranians for centuries. The relations between two nations have intensified since the birth of Islam to this date. As a result, many linguistic and cultural elements have been exchanged between two nations. Given that many words used today in our language have been borrowed from Arabic through Persian, the meaning of Persian for Turkish can be better understood [37].

The rate of achievement increase in the students speaking Russian is $37.24 \%$. This rate can be seen as low considering that there were Kazakh students in this group and that the Kazakh language has some common points with our language. Yet, the Kazakh students are educated in Russian in their own country; thus, they are more close to Russian and they are under the influence of Russian. Therefore, it seems to be necessary to investigate the stress rules of Russian. In Russian, stress is important. In Russian, there are no rules of stress and there are no certain places for stress in Russian words. Therefore, it is important to learn stress and pronunciation correctly [38]. Thus, it can be difficult for students speaking a language having no rule of stress yet placing a great importance on stress to learn the rules of stress in Turkish. Seen from this perspective, the rate of achievement increase in stressing the Turkish words obtained by the students speaking Russian can be considered a good increase.

In light of the findings of the current study, following suggestions can be made: While teaching the skill of stress in speaking training, sound analysis programs that allow students to repeat and practice and provide audio and visual feedbacks for students should be used. In computer assisted prosody training, individual differences 
of students learning Turkish as a foreign language and the mother tongues or official languages of students should be taken into consideration; comparisons should be made with the rules of stress in their own languages. There should be prosody laboratories in institutions teaching Turkish to foreigners. Moreover, pronunciation sections should be added to the textbooks written to teach Turkish to foreigners and computer assisted pronunciation materials should be prepared.

\section{Acknowledgements}

This study is based on Gurbet Sarıman's Master's dissertation titled The Effect of Computer Aided Education on the Skill of Word Stressing in Teaching Turkish as a Foreign Language, Institute of Educational Sciences, Muğla Sitkı Koçman University.

\section{REFERENCES}

[1] Sığırcı, İ. Türkiye'Nin Üyeliği Açısından Avrupa Birliği Dil ve Kültür Politikalar1. C International Journal of Language Academy, Vol. 3/3, 83-97, 2015.

[2] Kenworthy, J. Teaching English Pronunciation, Longman, London, 1987.

[3] Rivers, W. M. Teaching Foreign-Language Skills, University of Chicago Press, 5801 S. Ellis Ave., Chicago, IL 60637, 1981.

[4] Demircan, Ö. Türkçenin Sesdizimi. Der Yayınevi, İstanbul, 1996.

[5] Avery, P., \& Ehrlich, S. (1987). Preliminary considerations in the teaching of pronunciation. London: TESL Center.

[6] Yilmaz, İ., Şeref, İ. Arap Öğrencilerin Türkçe Okuma Sesletim Becerilerinin Geliştirilmesinde Şiirden Yararlanma, Uluslararası Türkçe Edebiyat Kültür Eğitim Dergisi, Vol. 4, No. 3, 1213-1228, 2015.

[7] İlgün, K. Yabancı Dil Olarak Türkçenin Öğretiminde Telaffuz Becerisini Geliştirmeye Yönelik Tekerleme Ve Ninnilerin Kullanım1, Master's Thesis, Institute of Educational Sciences, Gazi University, Ankara, 2015.

[8] Özkan, H. Teaching Word Stress to ELT Freshman Students Through Computers, Master's Thesis, Department of English Language Teaching, Institute of Social Sciences, Hacettepe University, Ankara, 2010.

[9] Tüm, G. Çok Uluslu Sinıflarda Yabancı Dil Türkçe Öğretiminde Karşılaşılan Sesletim Sorunları, Journal of Education, Hacettepe University, Vol. 9, No. 2, 255-257, 2014.

[10] Çetin, D. Bilgisayar Destekli Prozodi Eğitiminin Vurgu, Ton ve Duyguyu Algilama ve Yansitma Becerilerine Etkisi, Doctoral Thesis, Institute of Educational Sciences, Gazi University, Ankara, 2013.
[11] Bagshaw, P. C. Automatic Prosodic Analysis for Computer Aided Pronunciation Teaching, Unpublished Doctoral Dissertation, University of Edinburgh, 1994.

[12] Hardison, D. M. Contextualized Computer-Based L2 Prosody Training: Evaluating the Effects of Discourse Context and Video Input, CALICO Journal, 22, 715-190, 2005.

[13] Fujimori, A., Yoshimura, N., Yamane, N. The Development of Visual CALL Materials For Learning L2 English Prosody, ICT for Language Learning Conference Proceedings, 12-13 November 2015, Florence, Italy, Libreriauniversitaria.it, 247-254, 2015.

[14] Çetin, D. Dil Becerileri-Anlatma (Konuşma ve Yazma Becerileri). H. Develi et al. (Ed.), Uygulamalı Türkçenin Yabancı Dil Olarak Öğretimi El Kitab1-I , 359-424, 2017.

[15] Coşkun, M. V. Türkiye Türkçesinde Vurgu, Ton ve Ezgi, Türk Dili Araştırmaları, 584: 127.c, 2000.

[16] Demircan, Ö. Türkçenin Ezgisi, YTÜ Basım-Yayın Merkezi, İstanbul, 2000.

[17] Akbayır, S. Dil ve Diksiyon Yazılı ve Sözlü Anlatım Bozuklukları (2. Edition), Akçă̆ Yayınları, Ankara, 2003.

[18] Bilgin, M. Anlamdan Anlatıma Türkçemiz (2. Edition), An1 Yayınc1lık, Ankara, 2006.

[19] Özbay, M. Sesle İlgili Kavramlar ve Konuşma Eğitimi, Millî Eğitim Dergisi, 168, 116-125, 2005.

[20] Dursunoğlu, H. Türkiye Türkçesinde Vurgu, Sosyal Bilimler Enstitüsü Dergisi, Atatürk University, Vol. 7, No. 1, 269-270, 2006.

[21] Demir, İ. Türkçe Sözcüklerde Vurgu, Turkish Studies-International Periodical For the Languages, Literature and History of Turkish or Turkic, Vol. 4, No. 4, 207-235, 2009

[22] Kabak, B. ve Vogel, I. The Phonological Word and Stress Assignment in Turkish, Phonology, Vol. 18, No. 03, 315-360., 2001.

[23] Ergenç, İ. Türkiye Türkçesinin Görevsel Ses Bilimi, Engin Yayınevi, Ankara, 1989.

[24] Fidan, D. Türkçede Ezgi Örüntüleri, Master's Thesis, Institute of Social Sciences, Ankara University, 2002.

[25] Börekçi, M. Türkçede Vurgu -Tonlama - Ölçü - Anlam İlişkisi, Atatürk University Kazım Karabekir Eğitim Fakültesi Dergisi, 12, 187-207, 2005.

[26] Taşer, S. Örneklerle Konuşma Eğitimi, Papirüs Yayınevi, İstanbul, 2006.

[27] Vural, B. Doğru ve Güzel Konuşma, Hayat Yayınları, İstanbul, 2005.

[28] Gürzap, C. Konuşan İnsan, Yapı Kredi Yayınları, İstanbul, 2003.

[29] Ercilasun, A. B. Vurgu, Türk Dili ve Kompozisyon, 98-103, Ekin Kitabevi, Ankara, 2005.

[30] Leontiç, M. Türkçede Vurgu, BAL-TAM Türklük Bilgisi, Doi: ISSN 1452-2179, 273-282, 2015. 
[31] Isșı, A. ve Erol, E. İngilizce-Türkçe Karşılaștırmalı Dil bilgisi, Black Swan Publishing House, Ankara, 2012.

[32] Coşkun, M. V. Ana Dili Eğitiminde Parçalarüstü Birimlerin Önemi ve Teknoloji Destekli Olarak Kavratılması, Bilig, 48, 41-52, 2009.

[33] Rocca, P. D. A. New Trends on the Teaching of Intonation of Foreign Languages. New Sounds 2007: Proceedings of the Fifth International Symposium on the Acquisition of Second Language Speech, 2007.

[34] Hirata, Y. Computer Assisted Pronunciation Training for Native English Speakers Learning Japanese Pitch and Durational Contrasts. Computer Assisted Language Learning, Vol. 17, No. 3-4, 357-376, 2004.
[35] Büyüköztürk, S., Kılıç Çakmak, E., Akgün, Ö.E., Karadeniz, Ş. ve Demirel, F. Bilimsel Araştırma Yöntemleri, Pegem Yayınları, Ankara, 2012.

[36] Cylwik, N., Demenko, G., Jokisch, O., Jäckel, R., Rusko, M., Hoffmann et al. The Use Of Call In Acquiring Foreign Language Pronunciation And Prosody-General Specifications For Euronounce Project, Proc. SASR, 123-130, 2008.

[37] Balc1, M. Türkçe-Farsça İlişkileri Türkçenin Farsça Üzerindeki Etkilerine Dair Bir İnceleme, Çizgi Kitabevi Yayınları, Konya, 2014.

[38] Online available: http://tr.russia.edu.ru/rus/169/ 